\title{
NÉHÁNY GONDOLAT A KVANTUMMECHANIKÁRÓL (HANKISS ELEMÉR EMLÉKÉRE)
}

\section{BRIEFLY ON QUANTUM MECHANICS (REMEMBERING ELEMÉR HANKISS)}

\author{
Kroó Norbert \\ az MTA rendes tagja, fizikus, a kőszegi Felsőbbfokú Tanulmányok Intézete Tanácsadó testületének tagja \\ info@iask.hu
}

\section{ÖSSZEFOGLALÁS}

\begin{abstract}
A kvantummechanika világképe gyökeresen eltér a mindennapi tapasztalatainkon alapuló képtől. Míg a klasszikus fizika építhetett a hagyományos matematika eredményeire, a kvantummechanika radikálisan új matematikát kívánt. A 20. századnak ez a legsikeresebb elmélete a mikrovilág leírására született, az elemi részek, atomok és molekulák világát írja le, mégpedig valószínűségi alapon. Három alapvető kvantummechanikai jelenséget ismerünk, az egyik a részecske-hullám kettősség, a második az úgynevezett alagúteffektus, a harmadik pedig, a talán mindennapi tapasztalatainkhoz képest a legfurcsább, ez az úgynevezett szuperpozíció és összekapcsoltság jelensége. Az élő rendszerekben is megjelennek a kvantumos folyamatok, ezért a biológiai folyamatok - az emberben zajló életfolyamatok is - ezen nem klasszikus volta döntő fontosságú életünk minden szegletében. Hankiss Elemér felfigyelt arra, hogy megjelent egy sor munka, amelyek bizonyos társadalmi jelenségeket is a kvantummechanika törvényei alapján próbáltak megmagyarázni. Ezért tartom indokoltnak, hogy az ő emlékére egy rövid bepillantást tegyek a kvantummechanika rejtelmeibe, eljutva néhány, a társadalomtudományokba is behatoló gondolatig.
\end{abstract}

\section{ABSTRACT}

Spookiness of the quantum world of microsystems comes from being completely different from what we experience in our everyday life. Particle-wave duality, the tunnelling effect, superposition and entanglement, the typical phenomena of the quantum world are difficult to understand on the basis of daily experience. While the classical world can be described by exact equations, the quantum world can be grasped only probabilistically. This requires a new form of mathematics as well. Quantum mechanics penetrates from the non-living material world to the biological one and through biology into human and social phenomena. Elemér Hankiss became involved in the latter issues in the last years of his life. That is why it is appropriate to offer some thoughts on quantum mechanics to his memory.

Kulcsszavak: Hankiss, Kőszeg, részecskehullám, kvantummechanika, szociológia, atom, molekula Keywords: Hankiss, Kőszeg, particle wave, quantum mechanics, sociology, atom, molecule 
Élete utolsó éveiben Hankiss Elemér felfigyelt arra, hogy megjelent egy sor munka, amelyek bizonyos társadalmi jelenségeket is a kvantummechanika törvényei alapján próbáltak megmagyarázni. Meg is állapodtunk arról, hogy részletesebb eszmecserét folytatunk a témában, ezt azonban a közben bekövetkezett halála miatt már nem tudtuk megtenni. Ezért tartom indokoltnak, hogy az ő emlékének szentelve egy rövid bepillantást adjak a kvantummechanika rejtelmeibe, eljutva néhány, a társadalomtudományokba is behatoló gondolatig.

A klasszikus fizika Isaac Newton törvényeire épül. Ennek lényege, hogy ezek a törvények részecskepályákat írnak le. A részecske tömeggel rendelkezik, és pontszerü, oszthatatlan, tulajdonságai pedig megfigyelhetők és mérhetők. Minden rendszer részecskék halmaza, amelyek belső erökkel kölcsönhatnak egymással, de külső erőkkel kölcsönhatnak a külvilággal is. A rendszer állapotát a részecskék állapotának összege határozza meg, a részecskék tulajdonságait pedig elvileg végtelen pontossággal tudjuk megismerni. A klasszikus rendszerek kauzálisak, két azonos és azonos kezdeti feltételekkel rendelkező rendszeren végzett azonos mérés pedig azonos eredményt ad.

A kvantummechanika a mikrovilág elmélete, és a fentiektöl gyökeresen eltérő eredményeket ad ezen mikroszkopikus rendszerek esetén. Egy kvantumrendszerben a fizikai tulajdonságok mérése különböző lehetséges eredményekre vezethet, és a rendszer állapota ezek valamiféle „szuperpozíciója” lehet. A kvantummechanika valószínüségi elmélet, amely szerint nem figyelhető meg egy mikroszkopikus rendszer oly módon, hogy nem változnának meg bizonyos tulajdonságai. Nem mondható meg elöre ugyanakkor az sem, hogyan fog a rendszer állapota a mérés eredményeképpen megváltozni. A mikroszkopikus rendszereket továbbá az is jellemzi, hogy energiájuk kvantált. Végül pedig fontos megjegyezni, hogy ha a kvantummechanika törvényeit makroszkopikus rendszerekre alkalmazzuk, akkor azok a klasszikus fizika törvényeire redukálódnak.

Mindenekelött néhány mondat arról, hogy mi kényszerítette ki a kvantummechanika megszületését. Már a 19. század végén, de különösen a 20. század elején felmerültek olyan problémák, amelyeket a klasszikus fizika törvényei alapján nem lehetett megmagyarázni. Az első mindjárt egy alapprobléma volt: miért nem bomlanak el az atomok már néhány milliárdod másodperc alatt? Az elektronokról ugyanis már a múlt század elején, Ernst Rutherford kísérletei alapján is úgy gondolták, hogy azok az atommagok körül keringenek. A klasszikus fizika törvényei szerint elektromágneses sugárzást kellene ezeknek a gyorsulásuk (körpálya) miatt kibocsátaniuk, ami energiaveszteséget jelentene, és ennek eredményeképpen az atommagba kellene „hullaniuk”. Ez pedig nyilvánvalóan nem következik be. Egy másik probléma a meleg testek hősugárzása. A klasszikus fizika szerint növekvő hőmérséklet esetén az ultraibolya sugárzásnak gyorsan kellene növekednie, és ez úgynevezett ultraibolya katasztrófához vezetne, amit szintén nem figyeltek meg. Fény hatására szilárd testekből elektronok léphetnek 
ki, de egy anyagfüggő hullámhossznál nagyobb hullámhosszú fény intenzitását gyakorlatilag ,akármeddig” növelve sem lépnek ki elektronok az anyagból, alatta pedig ez már kisebb fényintenzitásnál is megtörténik. Azt sem érthetjük meg a klasszikus fizika törvényei alapján, hogy miért bocsátanak ki az atomok konkrét hullámhosszú fénysugarakat, és hogy ezek spektruma miért jellemző az aktuális atomokra. A 20. század első felében azonban ezek az érthetetlen problémák a születőben lévő és rohamosan fejlődő kvantummechanika törvényeinek alkalmazásával, Max Planck, Werner Heisenberg, Erwin Schrödinger, Albert Einstein és még sokan mások munkái alapján egyértelmủ magyarázatot kaptak.

Míg a klasszikus fizika építhetett a hagyományos matematika eredményeire, a kvantummechanika radikálisan új matematikát kívánt. A kvantumrendszerekben ugyanis a megfigyelhető mennyiségek nem számok, és nincs speciális értékük mindaddig, amíg nem mértük meg azokat. A mérés eredménye pedig eleve bizonytalan, a fizikai elmélet csak a különböző, lehetséges eredmények valószínűségét tudja megadni. A Heisenberg-féle határozatlansági reláció például a kvantumrendszer helye és sebessége bizonytalanságát határozza meg. Egyszerre egyiket sem mérhetjük meg pontosan. Minél pontosabban mérjük meg az egyiket, annál bizonytalanabb a másik. Ráadásul például ez a két mennyiség, a kvantumimpulzus (p) és a kvantumhely (x) olyan mennyiségek, amelyek az elemi matematika egyik alaptételét, a szorzás kommutativitását sértik $(\mathrm{x} \times \mathrm{p} \mathrm{p} \times \mathrm{x})$. A megfigyelhető mennyiségek tehát - szemben a klasszikus fizikával - egy nem kommutatív algebrát igényelnek.

Mindezeknek a jelenségeknek pedig az az eredményük, hogy a kvantummechanika világképe gyökeresen eltér a mindennapi tapasztalatainkon alapuló képtől. Ez a sikeres 20. századi elmélet, melyet az elmúlt évszázad minden kísérlete fényesen igazolt, a mikrovilág leírására született, az elemi részek, atomok és molekulák világát írja le, mégpedig - mint már említettem - valószínűségi alapon. Három alapvető tulajdonságát ismerjük a kvantumrendszereknek, az egyik a részecske-hullám kettősség, a második az úgynevezett alagúteffektus, a harmadik pedig, talán a mindennapi tapasztalatainkhoz képest a legfurcsább, az úgynevezett szuperpozíció és összekapcsoltság jelensége. Nézzük meg ezeket egyenként.

A hullám-részecske kettősség azt jelenti, hogy nem tudjuk egyértelmüen meghatározni például azt, hogy mi a részecske és mi a hullám. Ennek ellenére a kvantummechanika segítségével meg tudjuk magyarázni azokat a fizikai, kémiai, sőt biológiai jelenségeket, amelyek a klasszikus törvények alapján nem érthetők meg. Arra a következtetésre jutunk, hogy a természet megértéséhez az szükséges, hogy a fizikai objektumok, bármilyenek is legyenek azok, nem lehetnek sem kizárólagosan részecskék, sem hullámok. Semmilyen kísérlet sem mérheti mindkét tulajdonságot ugyanabban az időpontban, és ezért soha sem láthatjuk a részecske- és hullámtulajdonságok keverékét. Ha egy tárgyhoz köthető fizikai jelenséget figyelünk meg, a megfigyelt viselkedés - akár részecske, akár hullámszerü - a megfigyelés módjától függ. Ennek ellenére az objektum viselkedése matemati- 
kailag leírható, mégpedig olyan kvantummechanikai függvényekkel, amelyek valószínüségi jellegúek. Az alábbi táblázatban megkíséreltem összefoglalni a természetnek ezt a duális voltát, jelezve, hogy ezek a tulajdonságok a fény(hullám) és a részecskék esetében hol és hogyan jelennek meg.

1. táblázat (saját szerkesztés)

\title{
A TERMÉSZET DUÁLIS VOLTA A fizikai objektumok hullám-részecske dualitása
}

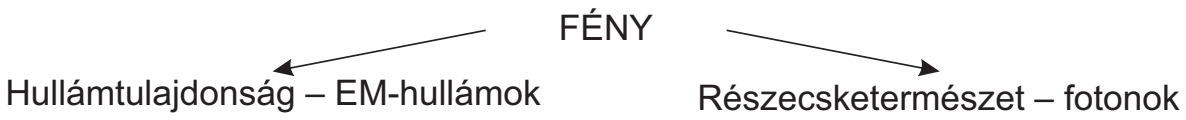 \\ Optikai mikroszkóp \\ Fényt elektromos árammá alakít \\ Interferencia \\ Foto-elektromos effektus (napelem)
}

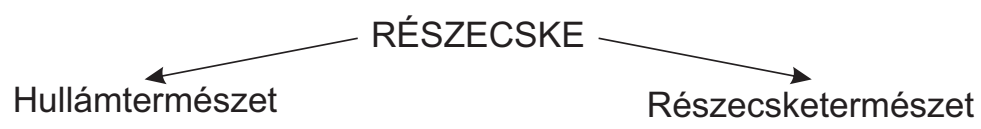

Anyaghullámok - elektronmikroszkóp

Elektomos áram

A határolt rendszerek diszkrét

foton-elektron ütközések

(kvantum) állapotai, pl. atomok

A fentiek fényében minden fizikai objektum mutathat mind hullám-, mind részecsketulajdonságokat. Ebből indult ki a kvantummechanika megalapozásában döntő szerepet játszó két kutató, Werner Heisenberg és Erwin Schrödinger is kvantumelméletük fejlesztése során. A fény részecsketulajdonságait írja le például az Einstein-egyenlet

$$
\text { fotonenergia }=\mathrm{h} \times(\text { a hullám frekvenciája })
$$

formában, ahol h egy természeti állandó. A részecskék hullámtulajdonságai pedig például a de Broglie-egyenlettel írhatók le, mégpedig a

$$
\text { hullámhossz }=\mathrm{h} /(\text { tömeg } \times \text { sebesség })
$$

alakban. 
A fizikai objektumot leíró matematikai függvényt hullámfüggvénynek nevezzük, a kísérletekben pedig az objektum megfigyelésének valószínűségét mérjük. A hullámfüggvény a kvantumrendszer állapotáról az összes információt tartalmazza. Ha például a rendszernek két realizálható állapota lehet, a hullámfüggvény

$$
\Psi(\mathrm{x}, \mathrm{t})=\mathrm{c}_{1} \Psi_{1}(\mathrm{x}, \mathrm{t})+\mathrm{c}_{2} \Psi_{2}(\mathrm{x}, \mathrm{t})
$$

és a $\Psi(\mathrm{x}, \mathrm{t})$ lineáris kombináció a lehetséges harmadik állapot. A $\mathrm{c}_{1}$ és $\mathrm{c}_{2}$ állandók komplex számok, $\mathrm{x}$ és t pedig a hely és az idő koordinátái.

Mindezek alapján azt mondhatjuk, hogy míg a „klasszikus világ” determinisztikus, egy adott időpontban tudhatjuk az objektumnak mind a helyét, mind a sebességét, és ha tudjuk az objektumra ható erőket, Newton egyenletei segítségével ki tudjuk számolni az objektum jövőjét. Ezzel szemben, mint fentebb említettem, a „kvantumvilág” valószínűségi jellegü, lehetetlen egy adott időpontban pontosan megmondani például a kvantumos objektum helyét és sebességét. Jövőbeli állapotát ezért a kvantummechanika egyenletei segítségével csak valószínűségi szinten tudjuk meghatározni, ha tudjuk a ható erők törvényeit. A megfigyelés lehetséges pontosságát a Heisenberg határozatlansági reláció adja meg. Ennek értelmében lehetséges a hely pontos meghatározása is, de akkor a sebességről semmit sem tudhatunk, és fordítva, a sebesség ismeretében a helyről nem tudunk semmit.

A második jelenség az alagúteffektus. Ennek lényegét jól szemlélteti az 1. ábra.

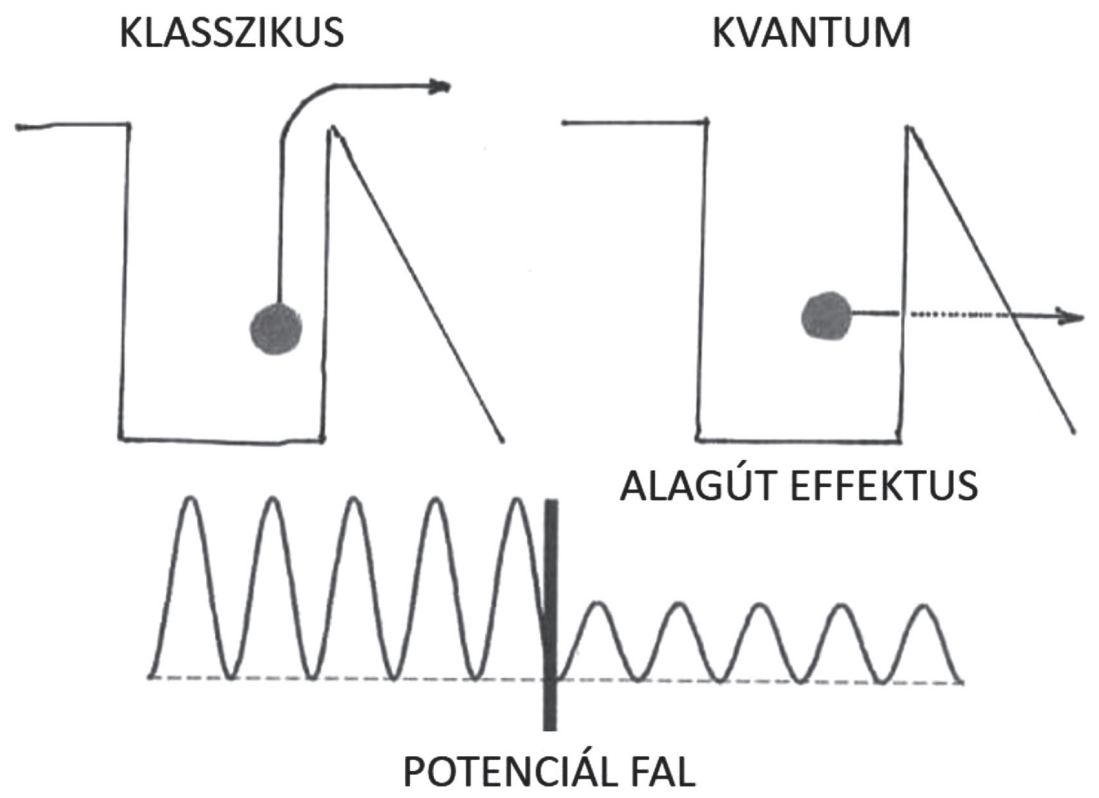

1. ábra. Alagúteffektus (saját szerkesztés) 
Az objektumok, ha azok egy úgynevezett potenciálgát által csapdába zárt állapotban vannak, a klasszikus törvények szerint külső segítség nélkül nem szabadulhatnak ki (1a). A kvantummechanika szerint azonban ezt bizonyos valószínűséggel megtehetik; (1b) és ezt a valószínüséget „kívülről” meg is tudjuk növelni. De szemléltethetjük az alagúteffektust egy „falba” ütköző hullámmal is. A klasszikus fizika szerint a hullám elakad. A kvantumfizika törvényei szerint azonban bizonyos valószínüséggel átbújik a falon (1c). A kvantumfizika és annak alkalmazásai számos ilyen esetet ismernek. Az élő és élettelen világ nagyszámú folyamata alapul ezen a jelenségen, de modern korunk technológiái (például a radioaktivitáson alapulók) vagy eszközei (például a tranzisztorok) is ezen alapulnak.

A kvantumvilág harmadik, „legfurcsább” tulajdonságcsoportja az úgynevezett szuperpozíció és az összekapcsoltság elve. A tulajdonságcsoport első elemét fentebb, a hullámfüggvény két realizálható állapotra való felírásakor már matematikai formában vázoltam. Ezt Erwin Schrödinger egyszerübben, egy dobozba zárt macska állapotával szemléltette (2. ábra).
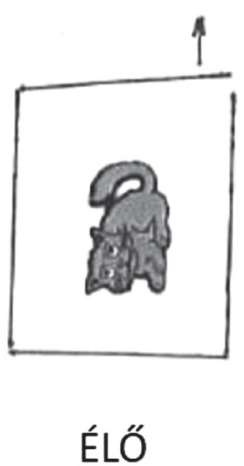

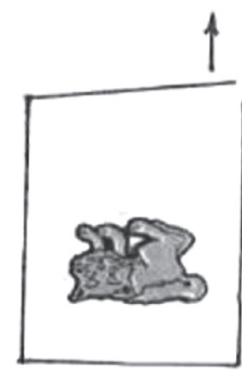

HALOTT

\section{MACSKA}

2. ábra (saját szerkesztés)

A macska 50-50\%-ban ( $c_{1}$ és $c_{2}$ ) lehet életben (2a) vagy halott (2b) mindaddig, amíg ki nem nyitjuk a dobozt, ez a cselekvés a kvantummechanikai mérés, amely feloldja a bizonytalanságot, és megtudjuk, hogy életben van-e a macska, vagy halott. Vagyis a mérés megváltoztatta a rendszer állapotát. Ennek a jelenségnek is számtalan formában jelenik meg a hatása világunkban.

Az összekapcsoltság (entanglement) pedig azt jelenti, hogy ha két kvantumobjektum ilyen összekapcsolt állapotban van, legyenek akármilyen távolságra egymástól, akár kozmikus távolságokra is, ha az egyik objektumban valamilyen változást hozunk létre, az azonnal kiderül a másiknál, amely követi ezt a változást. A 3. ábra ezt az összekapcsoltságot szemlélteti. Két elektron esetén 
ez például abban nyilvánul meg, hogy összekapcsoltságuk miatt spinjük (kis mágnestü) ellentétes irányú, és ha az egyik átfordul, azt a másik is késedelem nélkül követi (3. ábra).

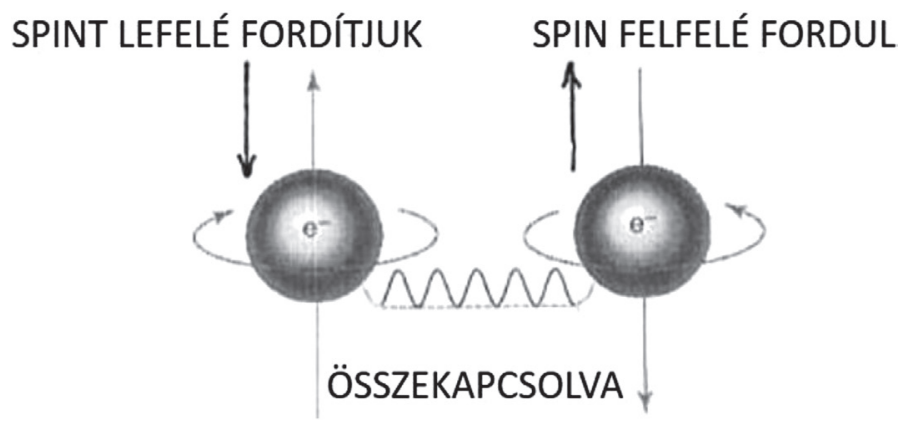

3. ábra (saját szerkesztés)

Ilyen összekapcsolt kvantumállapotokat pedig létre is tudunk hozni. Ezen alapul és egyre jobban kidolgozott a kvantumkriptográfia. Jelenleg már széles körben alkalmazzák ezt a lehetőséget, és előrehaladott kutatási fázisban van a műholdas kapcsolaton keresztüli kriptográfia is (Kína és Ausztria között).

A klasszikus számítógépeknél sokkal nagyobb teljesítményüek lehetnek a kvantumszámítógépek. Ezen utóbbiak müködése is a fenti kvantumjelenségek alkalmazásán alapul, a klasszikus gépekkel szemben ugyanis, ahol az igen-nem $(0,1)$ állapotokon alapszik a müködés, a többállapotú hullámfüggvények miatt a kvantumszámítógépek ennél sokkal szélesebb állapotválasztékra épülhetnek. A jelenlegi kutatási fázis legnagyobb gondja azonban az, hogy külső hatásra a kvantumrendszerek összekapcsoltsága könnyen elromlik (dekoherencia). Ezért a kutatások nagy része ezen dekoherencia-folyamat lelassítására irányul. Ezen probléma ellenére például az IBM cég már egy olyan, az egyik telephelyén müködő óriási teljesítményü kvantumszámítógépet ígér, amelyet a felhasználóknak bérmunkában fel tud ajánlani.

A kvantummechanika alkalmazási spektruma ennél az említett két lehetőségnél jóval szélesebb. A legérzékenyebb szenzorok kvantumos jelenségeken alapulnak. A mágneses és elektromos terek igen finom érzékelése, kémiai reakciók követése, ultraérzékeny mágneses rezonancia eszközök, vagy a nanovilág pásztázó alagútmikroszkópja ilyen alkalmazások, de hosszú sorát lehetne felsorolni azon további érzékelőknek és más eszközöknek, melyek a kvantumos jelenségeket használják ki. A kémiai és biológiai reakciók is a kvantummechanika törvényei szerint zajlanak.

Ami pedig ezen utóbbiakat illeti, sokáig úgy gondolták, hogy a biológiai folyamatokban, ahol a víz és a meleg fontos szerepet játszik, nem érvényesülnek a kvantummechanika törvényei. Úgy gondolták, hogy a biológiában a kvantum- 
folyamatok „kiátlagolódnak”, és minden a klasszikus törvények szerint zajlik. Az elmúlt évtizedekben kiderült azonban, hogy ez nincs így. Például a madarak a Föld mágneses terének segítségével molekuláris kvantumfolyamatok alkalmazásával tájékozódnak; az életfolyamatainkhoz szükséges energia pedig, amelyet a fotoszintézis segítségével gyüjtünk be a napsugárzásból, ugyancsak ezen folyamatokon alapul. A levélre eső foton energiája bonyolult kvantummechanikai folyamat útján jut el az úgynevezett reakcióközpontba, ahol a foton energiája kémiai formában tárolódik. A napenergia természeti begyüjtésének hatásfoka közel $100 \%$, messze hatékonyabb, mint bármely általunk kifejlesztett technológiáé.

A fizikai folyamatok világosan demonstrálják a fentebb vázolt jelenségeket, sőt ki is használják azokat, de a fent említettekben és még sok más esetben is (például idegmüködés, látásérzékelés stb.) az utóbbi évtizedekben megtanultuk, hogy a biológiai folyamatok is a kvantummechanika törvényei szerint zajlanak. Itt is a protonok és elektronok mozgása a meghatározó hajtóerő, ahogy ezt már sok évvel ezelött Szentágothai János is gondolta. De az utóbbi években azt is megtanultuk, hogy a szubatomi, atomi és molekuláris folyamatok makroszkopikus rendszerekbe is felskálázódhatnak. Például a fémek felületén létrehozható felületi plazmonok (amelyek a fém felületi elektronjai és az őket megmozgató külső elektromágneses tér [fény] házasságával hozhatók létre, és akár ezermilliárd elektron összehangolt, hullámszerú mozgását jelentik) is mutatnak kvantumos tulajdonságokat. De ahogy ez már fentebb is látható volt, az élő rendszerekben is megjelennek a kvantumos folyamatok, és ezért a biológiai folyamatok ezen nem klasszikus volta, beleértve az emberben zajló életfolyamatokat is, döntő fontosságú életünk minden szegletében.

Ez a kvantumosság többek között azt is jelenti, hogy az emberi agy is kvantumosan viselkedik, és ezért ez természetesen kihathat az egész emberi társadalomra és annak folyamataira is. Mivel a Heisenberg határozatlansági reláció müködik a kvantummechanikai rendszerekben, ezért a mérések, ugyanúgy, mint a fizikában, befolyásolják az emberi viselkedést (például a közvélemény-kutatók kérdései). De az emberi agy is szuperpozíciós (ellentmondásos) állapotban lehet, és talán ez magyarázhatja meg a gyakran irracionális döntéseinket. Az emberi tudat müködésében is kvantumos folyamatok játszanak szerepet. Sőt az is elképzelhető, hogy emberek viselkedésükben, reakcióikban ezen az alapon értelmileg/ érzelmileg összekapcsolhatók.

Lényegében hasonló gondolatokból kiindulva kezdett Hankiss Elemér a kvantummechanika társadalmi hatásaival foglalkozni. Ebben a témakörben írt dolgozatának címe: A kvantummechanika és az élet értelme.

Érdemes a tanulmányban szereplő meglátásokat továbbgondolni! 